\author{
В. А. Євтушенко, О. О. Свєженцев \\ Харківський національний університет імені В. Н. Каразіна \\ пл. Свободи, 4, м. Харків, 61022, Україна \\ E-mail: v.a.evtushenko@karazin.ua, ORCID: https://orcid.org/0000-0002-7764-2277

\section{СКЛАДОВІ ДЕРЖАВНОЇ ІННОВАЦІЙНОЇ ПОЛІТИКИ ТА МЕХАНІЗМ ÏI ЗДІЙСНЕННЯ У ВИМІРІ СВІТОВОГО ДОСВІДУ}

\begin{abstract}
Предметом дослідження $є$ сучасний інноваційний розвиток в умовах застосування системи інструментів державної інноваційної політики. Мета - систематизація наукових поглядів та аналіз критеріїв, складових та напрямків державної інноваційної політики, підходів до державної координаційної та регулюючої ролі в інноваційній політиці та, на цій основі, надання рекомендацій із застосування складових ефективної інноваційної політики країни. Методологічною базою для підготовки статті стали праці відомих іноземних та українських економістів 3 предмету дослідження, результати власних розробок, аналіз основних міжнародних індикаторів ефективного інноваційного розвитку країн світу. Для досягнення поставленої мети використані методи: діалектичний, історичний, логічний, системний, статистичний, графрічний. У результаті дослідження визначені сутність інноваційної політики держави та інноваційно-інвестиційні ризики, фактори, що гальмують інноваційний розвиток українських підприємств, і функції державної інноваційної політики. 3 метою розробки та реалізації результативної державної інноваційної політики проаналізовано ряд показників, які є складовими рівня успішності інноваційної політики країни, зокрема, співвідношення рівня витрат країни у відсотках до ВВП на наукові дослідження та інноваційні розробки, кількість оформлених громадянами країни патентів на інноваційні розробки (всередині країни та за кордоном), та цей же показник, але взятий у відношенні на один мільйон населення країни та співвідношення частки високотехнологічної та середньо-технологічної продукції країн міжнародного інноваційного рейтингу та середньої облікової ставки центральних банків країн. В роботі запропонована концепція державної підтримки розробки та впровадження інновацій у реальний сектор економіки.
\end{abstract}

Ключові слова: державне регулювання економіки, інновація, інноваційна політика, інноваційно-інвестиційний ризик, національна економіка.

JEL Classification: O32; O38; O57.

Viktoriia Yevtushenko, Oleksandr Sviezhentsev

V.N. Karazin Kharkiv National University

4 Svobody Sq., 61022, Kharkiv, Ukraine

E-mail: v.a.evtushenko@karazin.ua, ORCID: https://orcid.org/0000-0002-7764-2277

\title{
COMPONENTS OF STATE INNOVATIVE POLICY AND THE MECHANISM OF ITS IMPLEMENTATION IN THE MEASUREMENT OF THE WORLD EXPERIENCE
}

The subject of the research is the modern innovative development in the conditions of application of the system of the state innovation policy instruments. The purpose is to systematize scientific views and analyze the criteria, components and directions of the state innovation policy, approaches to coordinating and regulatory role of the state in innovation policy and, on this basis, to make recommendations on the application of the components of an effective innovation policy of the country. The methodological basis for the article was the works of well-known foreign and Ukrainian economists on the subject of research, the results of the authors' own research, analysis of the main 
international indicators of effective innovation development of the countries of the world. To achieve the goal, the following methods were used: dialectical, historical, logical, systemic, statistical and graphical. As a result of the research, the essence of innovation policy of the state and innovation and investment risks, factors hindering the innovative development of Ukrainian enterprises and functions of state innovation policy were determined.

In order to develop and implement an efficient state innovation policy, a number of indicators that are components of the successful innovation policy of the country were analyzed, in particular, the ratio of the country's expenditure on research and development as a percentage of GDP, the number of patents issued to the country's citizens for innovations (within the country and abroad), and the same indicator but per million in the population of the country as well as the ratio of the share of high-tech and medium-tech products of the countries listed in the international innovative rating and the average interest rate of the country's central bank. The concept of the state support for the development and implementation of innovations in the real sector of the economy is offered in this paper.

Keywords: state regulation of economy, innovation, innovation policy, innovation-investment risk, national economy.

JEL Classification: O32; O38; 057.

В. А. Евтушенко, А. А. Свеженцев

Харьковский национальный университет имени В. Н. Каразина, пл. Свободы, 4, 61022, Харьков, Украина

E-mail: v.a.evtushenko@karazin.ua, ORCID: https://orcid.org/0000-0002-7764-2277

\section{СОСТАВЛЯЮЩИЕ ГОСУДАРСТВЕННОЙ ИННОВАЦИОННОЙ ПОЛИТИКИ И МЕХАНИЗМ ЕЕ ОСУЩЕСТВЛЕНИЯ В ИЗМЕРЕНИИ МИРОВОГО ОПЫТА}

Предметом исследования является современное инновационное развитие в условиях применения системы инструментов государственной инновационной политики. Цель систематизация научных взглядов и анализ критериев, составляющих и направлений государственной инновационной политики, подходов к государственной координационной и регулирующей роли в инновационной политике и, на этой основе, предоставление рекомендаций по применению составляющих эффрективной инновационной политики страны. Методологической базой для подготовки статьи стали труды известных иностранных и украинских экономистов по предмету исследования, результаты собственных разработок, анализ основных международных индикаторов эффрективного инновационного развития стран мира. Для достижения поставленной цели использованы методы: диалектический, исторический, логический, системный, статистический, графический. В результате исследования определены сущность инновационной политики государства и инновационноинвестиционные риски, фракторы, тормозящие инновационное развитие украинских предприятий, и функции государственной инновационной политики. С целью разработки и реализации результативной государственной инновационной политики проанализирован ряд показателей, которые являются составляющими уровня успешности инновационной политики страны, в частности, соотношение уровня расходов страны в процентах к ВВП на научные исследования и инновационные разработки, количество оформленных гражданами страны патентов на инновационные разработки (внутри страны и за рубежом), и этот же показатель, но взятый в отношении на один миллион населения страны, а также соотношение доли высокотехнологичной и среднетехнологической продукции стран международного инновационного рейтинга и средней учетной ставки центрального банка стран. В работе предложена концепция государственной поддержки разработки и внедрения инноваций в реальный сектор экономики.

Ключевые слова: государственное регулирование экономики, инновация, инновационная политика, инновационно-инвестиционный риск, национальная экономика.

JEL Classification: O32; O38; O57.

Постановка проблеми. Сучасний етап розвитку глобальної економіки характеризується прискоренням науково-технічного прогресу та зміною технологічного устрою. Кількість 48 
ефрективних та перспективних інновацій, активізація створення та впровадження інновацій $є$ одними з найважливіших проблем розвитку як для розвинутих країн, так й для тих, які активно розвиваються. Сьогодні зростання структурної частки високотехнологічної промисловості, інтелектуалізація економіки, підвищення кількості впроваджуваних запатентованих інноваційних розробок, збільшення обсягів виробництва інноваційних товарів - $€$ метою інноваційної політики кожної країни. В умовах появи новітніх швидкозростаючих галузей виробництва, у країн, які розвиваються, з'явилась можливість наздогнати передові країни за рівнем технологій , досягти сталого розвитку та, як наслідок, підвищити доходи населення. Тому рівень та ефективність здійснення державної інноваційної політики стали однією 3 найважливіших проблем макроекономічного розвитку.

Аналіз останніх досліджень і публікацій та невирішені складові загальної проблеми. Теоретико-методичним основам вирішення проблем макроекономічного інноваційного розвитку, пошукам методів стимулювання інноваційної діяльності національних підприємств та, зокрема, формування державної інноваційної політики присвячено праці В. Гейця (Геєць, 2015), А. Гриценка (Гриценко, 2015), А. Даниленка (Даниленко, 2015), P.Нельсона (Nelson, 1993), Б.Лундвала (Lundvall, 2007), Л.Соете (Soete, 2010), Б.Верспагена (Verspagen, 2010), Н. Терьошкіної (Терьошкіна, 2015), Л. Лебедевої (Лебедева, 2014), О. Головінова (Головінов, 2013), І. Анісімова (Анісімов, 2015), О. Макара, 3. Юринець (Юринець, 2016), Б. Соріна (Сорін, 2016) та багатьох інших науковців.

У світовій економічній науці виокремився напрямок вивчення та аналізу «національних інноваційних систем», сучасними представниками якого є P.Нельсон (Nelson, 1993), Б.Лундвал (Lundvall, 2007), Л.Соете (Soete, 2010), Б.Верспаген (Verspagen, 2010) та інші вчені. Загальними рисами всіх робот даного напрямку $€$ твердження про необхідність створення в кожній країні національної інноваційної системи (НIC), а також аналіз відмінностей між різними HIC країн, питання оптимальної структури НIC та її взаємодії з ринковим середовищем. Теорія створення НIC в певній мірі опонує неокласичному ринковому підходу, тому що створення НІС передбачає певний державний координаційний та інституційний вплив на ринкову систему. Зокрема, цей підхід відкидає ідею «цілком раціональних і всезнаючих економічних суб'єктів» та сумнівається в оптимальності політики невтручання у ринкову систему. Відповідно, він бачить інститути, які створені державою, як центральні для сприяння накопиченню та передачі інновацій та технологій у процесах взаємодії інноваторів, науковців, кредиторів та державних інститутів. Наприклад, Л.Соете та Б.Верспаген (Soete, Verspagen, 2010, с.17) вважають, що роль держави - "впливати на природу бази знань про фрірми та збільшити поглинаючу інноваційну здатність економіки, а також розвивати координацію між різними ринковими і неринковими акторами». Одним 3 найбільш системних та ґрунтовних документів щодо здійснення державної інноваційної політики є Національна доповідь «нноваційна Україна $2020 »$ (В.М. Геєць, А. Гриценко, А. Даниленко та ін., 2015), яку підготовлено Державною установою «Інститут економіки та прогнозування НАН України». Це - системний документ, який комплексно висвітлює виміри здійснення державної інноваційної політики у взаємозв'язку зі світовими тенденціями переходу міжнародної економіки на новий технологічний устрій, а саме: потенціал і тенденції інноваційного розвитку високотехнологічних та традиційних секторів економіки України, організаційно-технологічні фрорми інноваційної діяльності, фінансове забезпечення інноваційного розвитку, законодавче забезпечення науково-технічної та інноваційної діяльності, реалізацію освітньо-кваліфікаційних чинників інноваційної діяльності в Україні та ін.

Слід відзначити, що вітчизняні вчені по-різному аналізують структуру та роль інноваційного фактору економічного зростання, а також місце інновацій у державній політиці в цілому. Наприклад, Терьошкіна Н. Є. (Терьошкіна, 2015) порівнює терміни «інноваційна політика», «інноваційна стратегія», «науково-технічна політика». Лебедева Л. В. (Лебедева, 2014) системно проаналізувала стан, недоліки інноваційної політики України та шляхи її поліпшення. Головінов О.М. (Головінов, 2013) виявив проблемні питання інноваційної політики держави та можливість розробки концептуальних підходів до фрормування цілісної державної політики розвитку інноваційної економіки.

Анісімов І. Є. (Анісімов, 2015) охарактеризував стан інноваційної сфери в Україні та наголосив на необхідності розвитку цілеспрямованої регулюючої функції держави у сфері науково-дослідних та дослідно-конструкторських робіт (НДДКР), ії̈ відповідальності за загальну 
стратегію технологічного розвитку та підтримку наукомістких технологій і фундаментальних досліджень. Юринець 3. В. та Макара О. В. (Юринець та Макара, 2016) запропонували модель структуризації економічних засобів впровадження національної інноваційної стратегії для налагодження функціонування національної та регіональних інноваційних систем і на цій основі підвищення конкурентоспроможності економіки країни.

У працях Б. В. Соріна (Сорін, 2016) виявлено загальноекономічні та суспільно-політичні фрактори гальмування інноваційного розвитку українських підприємств, які унеможливлюють сталий інноваційний розвиток країни, та проаналізовано базові інноваційні індикатори, що визнані світовою практикою.

Проте, враховуючи цінність цих досліджень, на нашу думку, недостатню увагу приділено критеріям, складовим та оптимальній структурі державної інноваційної політики.

Натомість, зміни світової інноваційної парадигми та значне відставання вітчизняної економіки від передових країн, потребують термінового вдосконалення теорії та практики національного інноваційного процесу на мікро- та макрорівнях з використанням ефективних інструментів державного регулювання (Інноваційна Україна 2020, 2015), (Євтушенко, Сорін 2016).

Метою статті є дослідження взаємозв'язку між показниками, які відображають складові інноваційного процесу (доступність кредитних ресурсів в країні, первинна інституційна та фінансова підтримка інновацій та розмір вкладень країни у наукові, науково-дослідні та науково-технічні дослідження) та такими результуючими показниками як інноваційний рейтинг країни та рівень її високотехнологічного експорту; аналіз критеріїв, складових та напрямків державної інноваційної політики, підходів до державної координаційної та регулюючої ролі в інноваційній політиці та, на цій основі, надання рекомендацій із застосування складових ефрективної інноваційної політики країни в рамках створення національної інноваційної системи (HIC), вдосконалення теорії та практики національного інноваційного процесу на мікро- та макрорівнях з використанням ефективних інструментів державного регулювання.

Виклад основного матеріалу дослідження. Аналіз вищенаведеного наукового надбання дозволяє окреслити основні терміни та закономірності, що характеризують предмет дослідження.

Інноваційна політика держави - система дій органів державної влади, які спрямовані на організацію та координацію процесу створення, удосконалення та впровадження інновацій заради досягнення найбільш ефективного результату в кількості та якості діючих новітніх технологій. Це є метою комплексних заходів з організації інституційних, фрінансових, ресурсних умов для створення та впровадження інноваційних розробок, а також підвищення конкурентоспроможності вітчизняних товарів, удосконалення нормативних документів та створення привабливого бізнес-середовища для створення новітніх технологій.

Інноваційна політика є частиною соціально-економічної, промислової та наукової політики держави, завданням якої є постійне технологічне оновлення промисловості та впровадження інноваційних розробок у серійне виробництво. Це підвищує конкурентоздатність та доходи економіки країни, має позитивний соціально-економічний ефект для країни в цілому.

В цілому, інноваційна політика держави має виконувати такі функції (рис. 1).

В умовах змішаної ринкової економіки, яка включає в себе як державні, так і приватні установи та підприємства, включаючи малі інноваційні та венчурні підприємства, державна промислова та інноваційна політика має бути різноманітною з метою найбільш ефективного розвитку всіх галузей та всіх типів економічних суб'єктів. Для державних підприємств сама держава має бути координатором та менеджером інноваційного розвитку, створюючи умови для розробки, тестування, впровадження у виробництво інновацій, залучаючи до цього процесу приватний бізнес. Для приватного сектору держава має бути регулятором, який за допомогою нормативно-законодавчих актів створює умови для стимулювання розробки та впровадження інновації. В свою чергу, важливою задачею державної інноваційної політики $\epsilon$ об'єднання освіти (підготовка кваліфікованих спеціалістів), науки (фундаментальні та практичні наукові дослідження), виробництва (впровадження перспективних інноваційних розробок у серійне виробництво). Загальноекономічною функцією інноваційною політики держави $€$ визначення пріоритетів в інноваційній сфері для економічних агентів всіх форм власності.

Механізм державного регулювання інноваційної діяльності не $є$ самоціллю, а є цілком підпорядкованим завданню нівелювання гальмуючих інноваційний розвиток факторів (див. 
таблицю 1), досягнення оптимальних пропорцій розширеного відтворення, високих темпів зростання національної економіки.

Основні складові механізму державного регулювання інноваційної діяльності: фрорми, методи, обсяги, напрямки, інструменти, економічні важелі та стимули, а також вибір і реалізація державної інноваційної стратегії в цілому є похідними від суспільного та державного устрою (Терьошкіна, 2015).

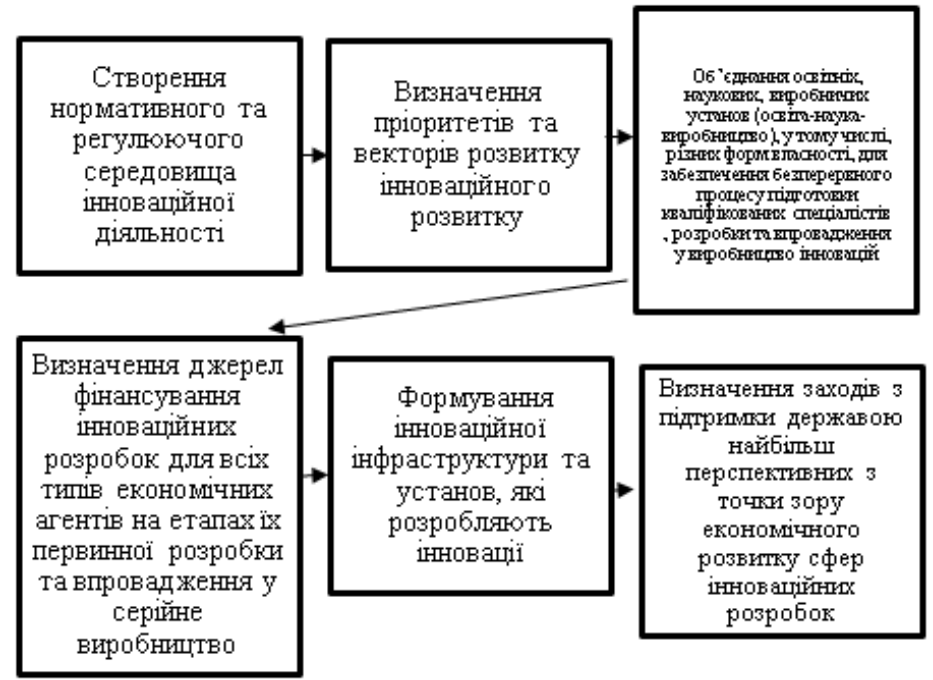

Рис. 1. Функції державної інноваційної політики.

\section{Джерело:складено авторами}

Таблиця 1

Типологізація фракторів, що гальмують інноваційний розвиток українських підприємств

\begin{tabular}{|c|c|c|}
\hline № & Фактори & Причини стримування інноваційного розвитку \\
\hline 1 & фрінансові & $\begin{array}{l}\text { відсутність коштів в межах окремого підприємства; відсутність } \\
\text { фінансування за межами підприємства; відсутність венчурного } \\
\text { фінансування; обмежений обсяг фінансування наукової діяльності з } \\
\text { державного бюджету; занадто високі витрати на інноваційну діяльність }\end{array}$ \\
\hline 2 & інформаційні & $\begin{array}{l}\text { відсутність інформації про технології та про ринки; відсутність } \\
\text { кваліфрікованого персоналу; неналежний рівень організації } \\
\text { інформаційного забезпечення, що перешкоджає розвитку науково- } \\
\text { дослідної діяльності }\end{array}$ \\
\hline 3 & ринкові & $\begin{array}{l}\text { домінування на ринку певних груп підприємств, що монополізували } \\
\text { традиційні галузі; незначний попит на інноваційні продукцію та послуги; } \\
\text { труднощі знаходження інвестиційних та інституційних партнерів } \\
\text { інноваційної діяльності; нерозвинутість процесів комерціалізації } \\
\text { інновацій; суспільна модель «надлишкового» споживання; відсутній } \\
\text { попит на інновації з боку як виробників, так й організаційних споживачів } \\
\text { (інноваційна бездіяльність) }\end{array}$ \\
\hline 4 & інституційні & $\begin{array}{l}\text { недосконалість інституційно-правових механізмів для забезпечення } \\
\text { формування ефективної системи органів публічного управління; } \\
\text { несформованість економічних стимулів щодо залучення інвестиційних } \\
\text { ресурсів в інноваційні процеси; недосконалість інституційного } \\
\text { забезпечення трансферу технологій; несформованість інноваційної } \\
\text { промислової політики та політики імпортозаміщення }\end{array}$ \\
\hline 5 & інфраструктурні & $\begin{array}{l}\text { нерозвинутість інноваційної інфраструктури: технопарків, технополісів, } \\
\text { високотехнологічних інноваційних підприємств, технокластерів, } \\
\text { венчурних фондів, центрів трансферу технологій та ін.; відсутність } \\
\text { технологічної кооперації в інноваційній сфері }\end{array}$ \\
\hline
\end{tabular}

Джерело: (Євтушенко, Сорін, 2016) 
На нашу думку, чим гіршою $є$ стартова ситуація в інноваційній сфері країни, тим більшим на початковому етапі повинен бути державний вплив та координація дій щодо розробки та впровадження інноваційних розробок, для того, щоб нові інноваційні підприємства наростили міць та стали конкурентоздатними.

Головними міжнародними рейтингами з інноваційності у сучасному світі є: Глобальний інноваційний індекс (Сайт The Global Innovation Index, 2018), топ-50 найбільш інноваційних країн світу (The Most innovative countries, Bloomberg), Глобальний індекс конкурентоспроможності (The Global Competitiveness Index), Європейське інноваційне табло (Innovation Union Scoreboard), топ-50 найбільш інноваційних компаній світу (The most innovative companies, BCG) (Сорін, 2016).

Інноваційний ризик в сенсі ризику невдалого впровадження інновацій присутній протягом всього процесу створення нових винаходів. Так само, в цьому процесі присутній інвестиційний ризик як ризик невдалого збиткового вкладення коштів, тому що життєвий цикл інновації неможливий без інвестиційних вкладень різних типів та форм, як на етапі вдосконалення, так і на етапі серійного виробництва. На етапі тестування інноваційної розробки інвестиції можуть бути представлені як державна допомога, приватні інвестиції або кошти зацікавлених осіб, на етапі серійного виробництва це - приватні венчурні або державні інвестиції, або кредитні кошти. 3 іншого боку, процес інвестування не завжди передбачає вкладення коштів в інноваційні розробки, наприклад,це можуть бути вкладення у існуючі середньо- або низькотехнологічні галузі з отриманням відповідно меншої норми прибутку. Тож, інвестиції та інновації дуже взаємопов'язані та, у певній мірі, разом впливають на процес інноваційного економічного зростання та зростання частки високотехнологічної промисловості. Тому, на наш погляд, доцільним $€$ формулювання термінів «інноваційно-інвестиційний ризик» та «інноваційно-інвестиційний розвиток».

В цілях досягнення мети дослідження показниками, які відображають рівень підвищення інноваційності економіки (та інтелектуалізації економіки), було обрано обсяг середньо- та високотехнологічної продукції відносно загального обсягу продукції країни та обсяг високотехнологічного експорту країни відносно загального об'єму експорту країни, а також інноваційний рейтинг країн світу (Сайт The Global Innovation Index, 2018), який щорічно складає Всесвітня організація інтелектуальної власності (ВОІВ, агентство ООН).

Виходячи зі стадій життєвого циклу інновації, проаналізуємо залежність показників успішності інноваційної політики від показників економіки країни, які є системними складовими інноваційної політики та в різній мірі впливають на її кінцевий результат (таблиця 2).

Таблиця 2

Показники, які характеризують стан інноваційної політики, виходячи зі стадій життєвого циклу інновації

\begin{tabular}{|c|l|}
\hline Стадія життєвого циклу інновації & \multicolumn{1}{|c|}{ Показники, що у певній мірі характеризують її стан } \\
\hline Виникнення та первинне & $\begin{array}{l}\text { Витрати на дослідження та розробки (R\&D) відносно } \\
\text { удосконалення інновації }\end{array}$ \\
\hline & $\begin{array}{l}\text { Кількість (та темпи зростання) зареєстрованих патентів } \\
\text { громадянами країни (в середині країни та за } \\
\text { пордоном), в абсолютних значеннях та скореговані на } \\
\text { кількість населення }\end{array}$ \\
\hline Впровадження інновації у серійне \\
виробництво
\end{tabular}

Джерело:складено авторами 
Витрати на наукові дослідження та розробки (gross expenditure on research and development) показують рівень фінансової первинної підтримки процесу створення та удосконалення інновацій та, зазвичай, розраховуються у відсотках до ВВП країни для зручності порівняльного аналізу.

Кількість та темпи зростання кількості зареєстрованих патентів громадянами країни (в середині країни та за кордоном), скореговані на рівень ВВП або на кількість населення $\epsilon$ показником рівня ефективності системи первинної підтримки інновацій країни, інституційних та фінансових дій держави, наслідком яких є запатентовані інноваційні рішення.

Рівень кредитних ставок центрального банку країни є тим показником, що впливає на рівень кредитних ставок, які встановлюють комерційні банки, і які $€$ «бар'єром» для впровадження інноваційного проекту, тому що рентабельність інвестиційного проекту має перевищувати рівень відсоткової ставки по кредиту. Доступні кредитні ресурси є необхідною (але не достатньою) умовою для зростання кількості впроваджених інновацій та для зростання прибутку від їх впровадження. Це особливо актуально для України та багатьох країн, що розвиваються, у яких політика центральних банків $є$ недостатньо стимулюючою у царині забезпечення доступними кредитними ресурсами суб'єктів економіки.

Прибуток від інновацій та кількість інновацій (патентів й ін.) залежить не тільки від низьких кредитних ставок, але й від системної підтримки інновацій: створення наукових шкіл, лабораторій, фінансова підтримка інновацій на первинному етапі розробки (вкладення в НДДКР), використання венчурних компаній. Підтримка інновацій на рівні стадії їх впровадження у виробництво залежить і від системної підтримки цього процесу з боку держави і бізнесу, їхніх спільних зусиль в цьому процесі, а також від наявності доступних кредитних ресурсів та рівня розвитку венчурних інструментів.

На рисунку 2 показано співвідношення інноваційного рейтингу країни (Global innovation index) 2017 року по 26 країнах та середній розмір облікових ставок центральних банків цих країн у 2013-2016 роках (у випадку країн Єврозони - це облікова ставка Європейського центрального банку), які прямо впливають на розмір вартості кредитів, в тому числі й кредитів, які надаються для реалізації інноваційних проектів. Період часу показників облікових ставок центральних банків (2013-2016) обрано з урахуванням середнього життєвого циклу інновації та того, що показник доступності залучення кредиту впливає на результативний показник інноваційності країни з певною затримкою у зв'язку з періодом реалізації та впровадження інновації. Співвідношення цих показників на графріку чітко вказує на те, що найкращі показники інноваційності у тих країн, які мають найменші облікові ставки центральних банків, та, відповідно, найбільш дешеві кредити для інноваційних проектів.

Дуже подібну ситуацію ми бачимо на рисунку 3, де показано співвідношення частки високотехнологічної та середньотехнологічної продукції країн інноваційного рейтингу (2017р.) та середньої облікової ставки центрального банку країни (2013-2016рр). Переважна більшість країн $з$ найбільшою часткою високотехнологічної та середньо-технологічної продукції 3 її загального об'єму мають низькі, близькі до нульових облікові ставки центрального банку країни, та, відповідно, дешеві (до 5\% річних) кредити для нових та вже існуючих виробництв. Чим більші кредитні ставки комерційних банків, тим більш важкою задачею $є$ зростання частки високотехнологічної промисловості, враховуючи переважно ліберальні умови та правила міжнародної торгівлі. Великі та непомірні кредитні ставки унеможливлюють зростання частки високотехнологічної та середньотехнологічної промисловості та $€$ перепоною для інноваційного розвитку країни в цілому. 


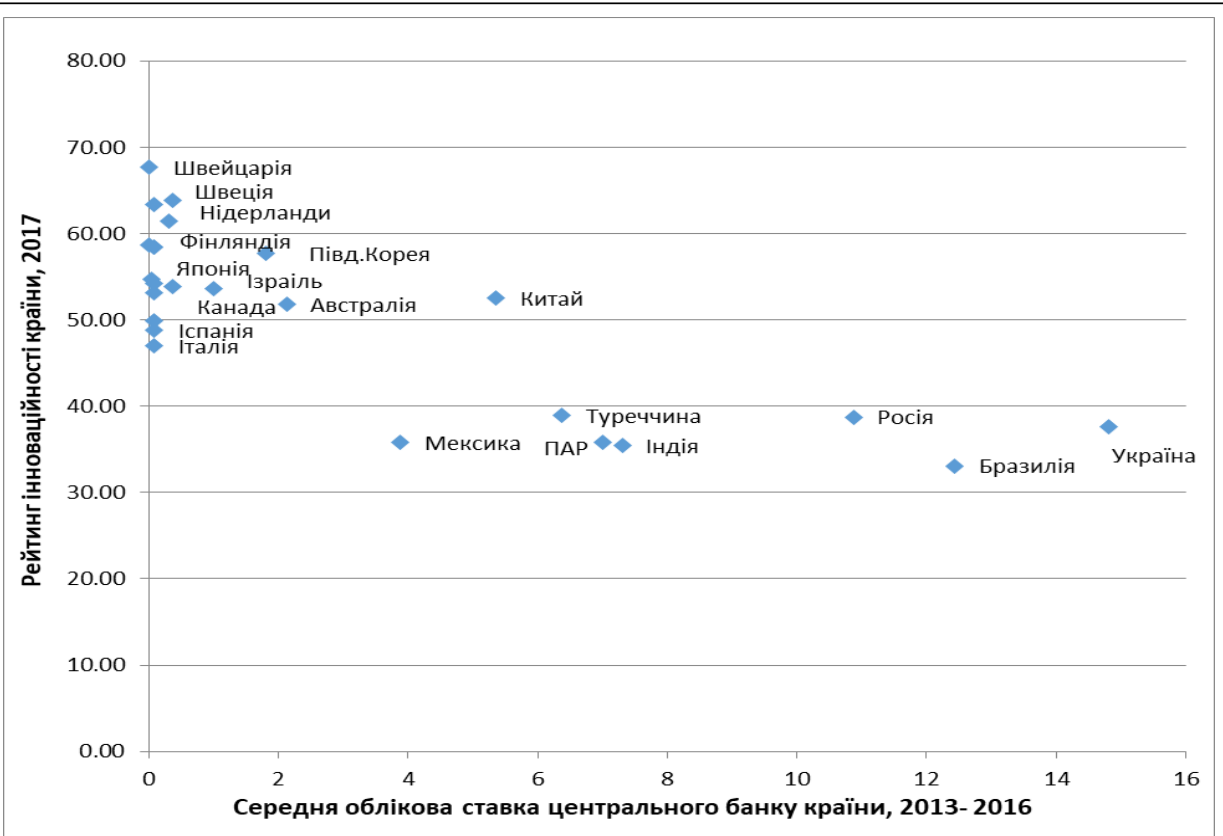

Рис. 2 - Співвідношення інноваційного рейтингу (2017р.) та середньої облікової ставки центрального банку країни (2013-2016 рр).

Джерело: (Сайm The Global Innovation Index, 2018; Caŭm Worldwide Central Bank Rates, 2018; Caŭm IMF Data International Financial Statistics, 2018)

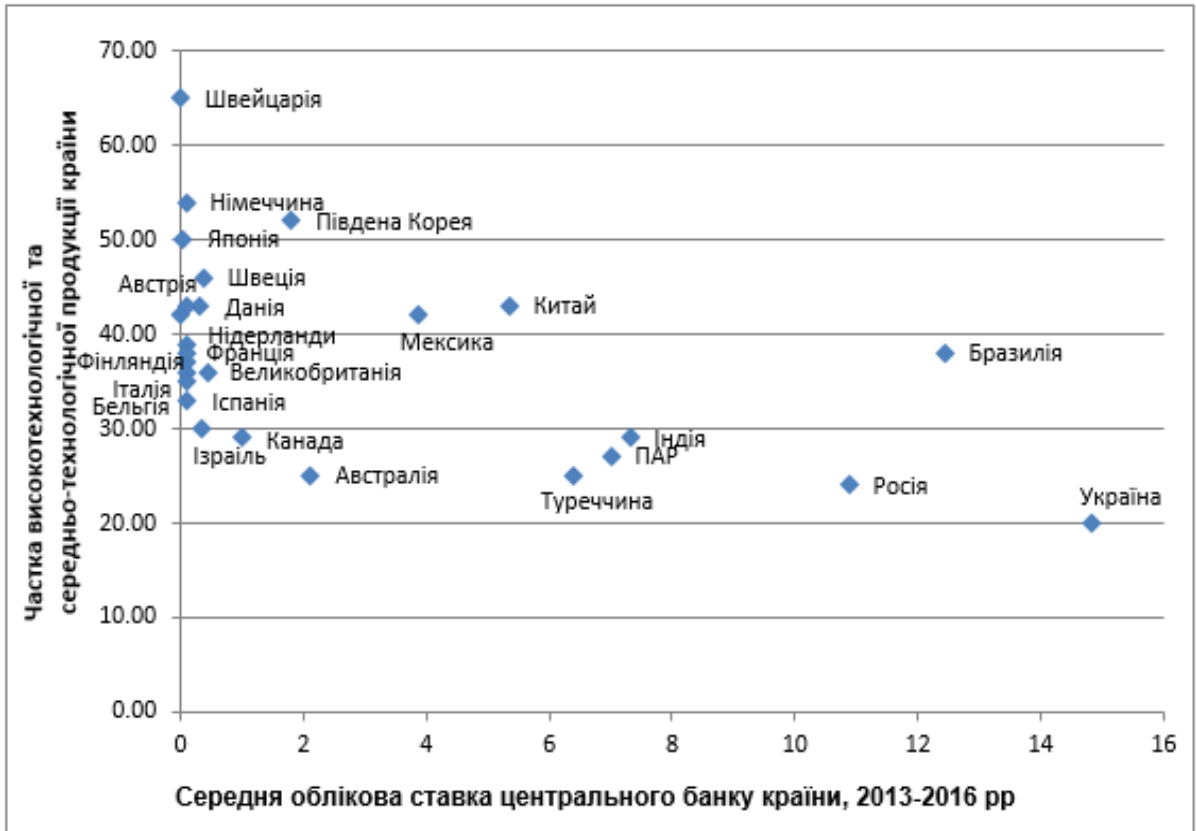

Рис. 3 - Співвідношення частки високотехнологічної та середньо-технологічної продукції країни інноваційного рейтингу (2017р.) та середньої облікової ставки центрального банку країни (2013-2016 рр).

Джерело: (Сайm The Global Innovation Index, 2018; Caŭm Worldwide Central Bank Rates, 2018; Caŭm IMF Data International Financial Statistics, 2018) 


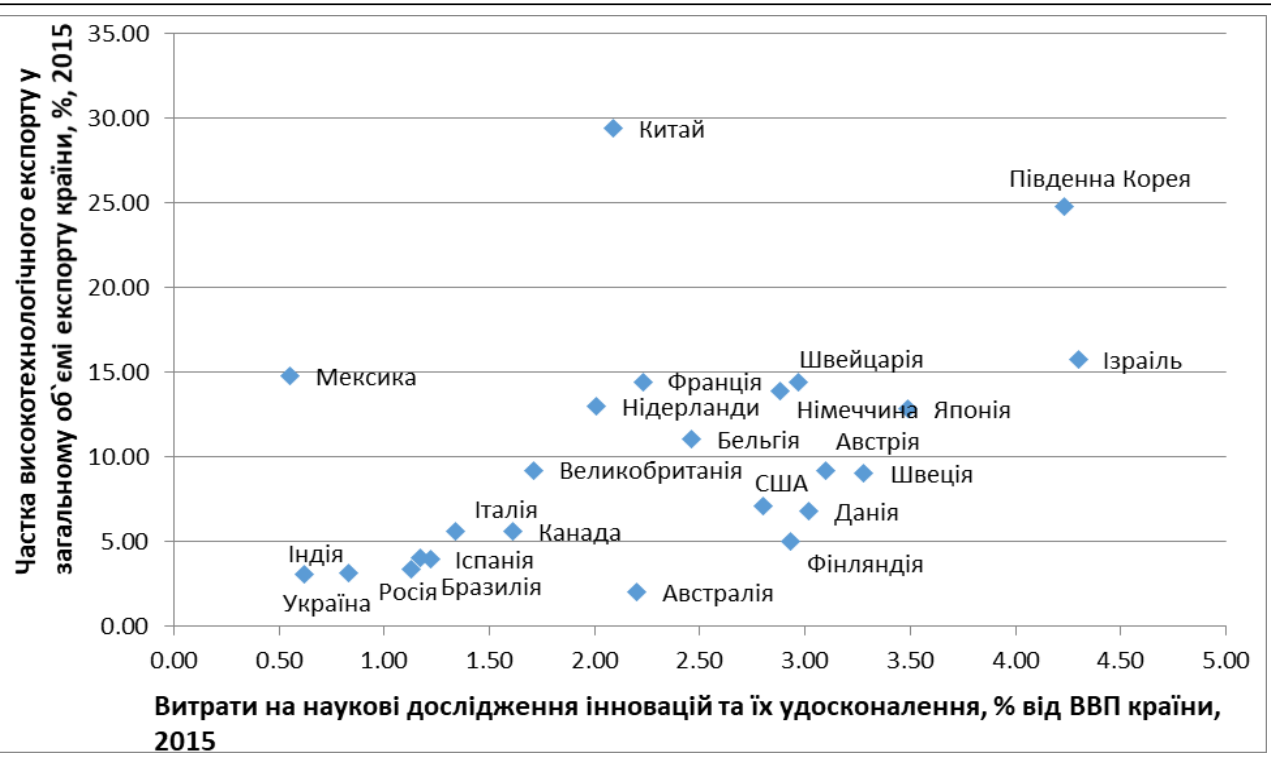

Рис. 4 - Співвідношення частки високотехнологічного експорту країни та рівня витрат країни у відсотках до ВВП на наукові дослідження та інноваційні розробки за 2015 рік. Джерело: (Сайm The Global Innovation Index, 2018)

Рисунок 4 показує взаємозалежність показників частки високотехнологічного експорту країни та рівня витрат країни у відсотках до ВВП на наукові дослідження та впровадження інновацій. Отже, досягнення високої частки високотехнологічного експорту та підвищення частки високотехнологічної промисловості неможливе без належного рівня витрат країни у відсотках до ВВП на наукові дослідження та інноваційні розробки. Окремо розташовані показники Мексики та Китаю. Показник високотехнічного експорту Мексики є вищим у зв'язку з переносом високотехнологічних виробництв з США та експортом готової продукції до США. Високий показник високотехнологічного експорту Китаю також зумовлений переносом високотехнологічних виробництв із високорозвинених країн, хоча Китай докладає величезних успішних зусиль та коштів для підвищення кількості інноваційних розробок всередині країни.

На рисунку 5 наведено взаємозалежність показника рівня витрат на наукові дослідження та інноваційні розробки (Gross expenditure on Research\&Development, витрати на R\&D) у відсотках до ВВП країни (2014) та показника оформлених патентів у розрахунку на один мільйон населення країни (2014). Рівень витрат на наукові дослідження та впровадження інновацій у великій мірі визначає як зростання виробництва у високотехнологічному сегменті промисловості та його частки в економіці в цілому, так й інноваційний рейтинг країни. Але для ефективності інноваційної політики мають значення не тільки розмір вкладень держави та бізнесу в інновації, а й ефективне використання цих коштів, створення системи підтримки та розробки інновацій (включаючи інституційну підтримку - освітню підготовку спеціалістів, надання їм інституційних та фінансових умов для роботи), наявну ситуацію зі створенням інновацій, враховуючи тривалий строк віддачі від вкладень у наукові розробки. Графрік на рисунку 5 показує, що, в цілому, показники рівня витрат країни у відсотках до ВВП на наукові дослідження та інноваційні розробки та показник кількості оформлених громадянами країни патентів на інноваційні розробки (всередині країни та за кордоном) у відношенні на один мільйон населення країни є прямо пропорціональними, але в рамках подібних значень рівня витрат на R\&D є коливання показнику кількості патентів, що відображає різну ефективність витрат на $R \& D$ в досліджуваних країнах та різницю їх інституційних умов. 
Якщо у показнику витрат на інноваційні розробки у відсотках до ВВП на рисунку 5 максимальна різниця між країнами, що взяті для аналізу, є десятикратною, то у кількості оформлених патентів, взятому на один мільйон населення країни, різниця між передовими країнами та країнами, що розвиваються $є$ ще майже чотирьохсоткратною. Це, на нашу думку, обумовлено різною ефективністю інноваційної політики та наявною ситуацією у сфері інноваційної діяльності країн, яку водночас змінити дуже важко. Свою роль у такій значній різниці між розвинутими країнами та країнами, що розвиваються, відіграє процес міграції вчених та розробників інновацій з менш розвинутих до більш розвинутих країн.

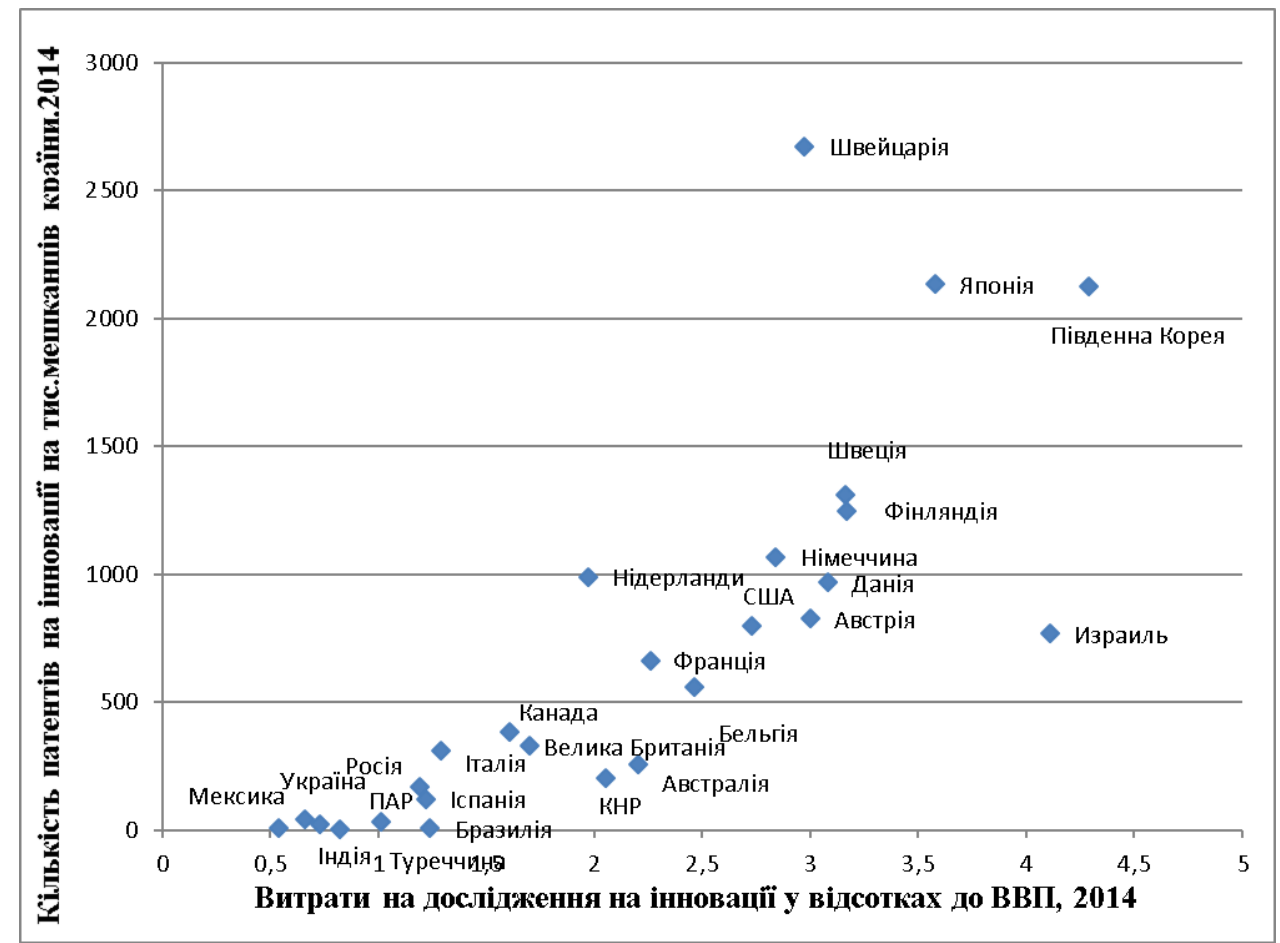

Рис. 5 - Співвідношення рівня витрат країни у відсотках до ВВП на наукові дослідження та інноваційні розробки, кількості оформлених громадянами країни патентів на інноваційні розробки (всередині країни та за кордоном),

взятий у відношенні на один мільйон населення країни

Джерело: (Сайm The Global Innovation Index, 2018; Caŭm WIPO International statistics property data center, 2018)

Ризиковий та специфічний характер інноваційної діяльності потребує наявності більшої координаційної ролі з боку держави для досягнення максимального результату, а саме: розробки і реалізації державної інноваційної політики, забезпечення довгострокових ризикових інвестицій, створення довгострокових стратегічних рішень, законодавчого регулювання інноваційної діяльності, сприяння формуванню інноваційного клімату, вибору стратегії та впровадження інновацій у неринковому секторі, освоєння і поширення базисних інновацій, сприяння створенню інноваційної інфрраструктури, підготовки кадрів для інноваційної діяльності.

Результат інноваційної політики є наслідком впливу їі складових, які зумовлені як необхідністю створення інституційних та фінансових умов для інновацій, так і послідовністю процесу впровадження технологічних рішень у серійне виробництво. 


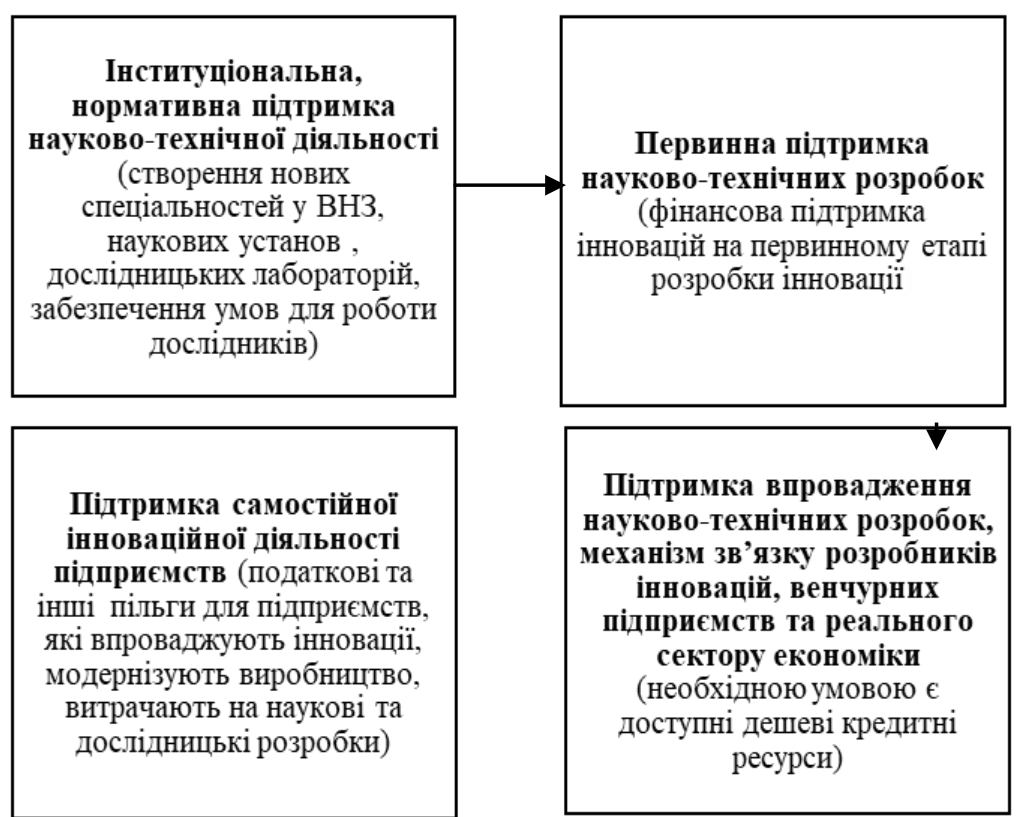

Рис. 6 - Механізм державної підтримки розробки та впровадження інновацій у реальний сектор

\section{Джерело:складено авторами} економіки.

Механізм координації та державної підтримки інновацій, який доцільно впровадити в умовах неналежної ситуації в інноваційній сфері України (див. рис. 6), можна умовно поділити на такі складові:

- обрання найбільш перспективних напрямів для інноваційних наукових досліджень та підготовки відповідних кваліфікованих спеціалістів;

- інституційна, системна підтримка інноваційної діяльності (створення нових спеціальностей у закладах вищої освіти, наукових установ, дослідницьких лабораторій, підготовка фрахівців);

- первинна державна підтримка (фрінансова підтримка інновацій на первинному етапі розробки, вкладення у НДДКР, допомога в патентуванні інноваційних розробок);

- державна та бізнес-підтримка впровадження обраних перспективних інновацій (інструменти впровадження: венчурні компанії, механізми пільгового кредитування тощо);

- створення комплексної системи дій 3 підтримки інноваційної діяльності, яка складається з податкових, митних, інституційних, фрінансово-кредитних та інших дій щодо стимулювання впровадження інновацій економічних суб'єктів.

В більш широкому розумінні інноваційна політика держави включає в себе: аналітичні заходи, науково-технічні заходи, інституціонально-організаційні заходи, бюджетно-податкові заходи, законодавчо-нормативні заходи (див. таблицю 1). Інноваційна політика регіону має більше дій практичного спрямування для стимулювання інноваційної діяльності, що включає підтримку розробників інновацій, їх взаємодію з установами, які надають фінансову та кредитну підтримку, та з організаціями, які зацікавлені у впровадженні інновацій. Також на регіональному рівні можуть бути задіяні координаційні, фрінансові, організаційні, науковотехнічні, аналітичні та інші методи та інструменти.

Висновки, наукова новизна, пропозиції та перспективи подальших досліджень. На основі даних розвитку провідних країн світу показано, що результативність інноваційної 
політики прямо залежить від доступності кредитних ресурсів в країні, первинної інституційної та фрінансової підтримки інновацій та розміру вкладень країни у наукові , науково-дослідні та науково-технічні дослідження. На жаль, на даний момент, стан сфери інноваційної діяльності в України знаходиться на незадовільному рівні. Показники інноваційної діяльності підприємств $€$ низькими та не сприяють підвищенню технологічного рівня розвитку економіки України. Інноваційна політика України має бути системною та науково обґрунтованою, включати в себе податкові, митні, інституційні, фрінансово-кредитні, стратегічно-організаційні стимули впровадження інновацій, підтримку інноваційних розробок установ всіх типів, забезпечення доступу винахідників до кредитних коштів за помірними ставками та сприяти процесу впровадження та комерціалізації інновацій венчурними фондами та приватними інвесторами. Враховуючи незадовільний стан сфери інноваційної діяльності в Україні, на початковому етапі активізації інноваційної діяльності доцільно впровадити запропонований механізм підтримки розробки та комерціалізації інновацій, в якому держава грає координуючу роль на всіх етапах розробки та впровадження інноваційних технологій. Напрямком подальших досліджень $€$ аналіз взаємозв'язків структурних елементів державної інноваційної політки та найбільш оптимальних співвідношень інструментів регулювання інноваційної сфери для максимізації результату інноваційного розвитку.

\section{Література}

1. Інноваційна Україна 2020: національна доповідь / за заг. ред. В.М. Гейця та ін.; НАН України. - К., 2015. - 336 с.

2. Nelson Richard, National Innovation Systems: A Comparative Analysis/R.Nelson.- New York Oxford: Oxford University Press, 1993. - 541p.

3. Lundvall B. National Innovation Systems-Analytical Concept and Development Tool/ Lundvall B. //Industry and Innovation.- 2007.-Vol 14.1.- p. 95-119.

4. Soete L., Verspagen B., ter Weel B. Systems of innovation/ L.Soete, B. Verspagen, and B. ter Weel// UNU-MERIT Working Papers.Maastricht Economic and social Research and training centre on Innovation and Technology.- Maastricht: UNU-MERIT, 2010.- 36p.

5. Терьошкіна Н. Є. Інноваційна політика як інструмент реалізації національної інноваційної стратегії / Н. Є. Терьошкіна // Економіка розвитку. - 2015. - № 2. - С. 21-29.

6. Лебедева Л. В. Сучасна інноваційна політика держави в Україні: проблеми та перспективи реформування / Л. В. Лебедева // Ефективна економіка. - 2014. - № 1. [Електронний ресурс]. - Режим доступу: http://www.economy.nayka.com.ua/?op=1\&z=2664.

7. Головінов О. М. Інноваційна політика держави: реалії і проблеми / О. М. Головінов // Економічний вісник університету : зб. наук. пр. Переяслав-Хмельницького державного педагогічного університету ім. Г. Сковороди. - 2013. - Вип. 21(1). - С. 16-21.

8. Анісімов І. Є. Державна політика України щодо розвитку інноваційної діяльності в умовах економічної кризи / І. Є. Анісімов // Вісник Приазовського державного технічного університету. Серія: Економічні науки. - 2015. - Вип. 30. - С. 255-261.

9. Юринець 3. В. Інноваційна політика як інструмент підвищення конкурентоспроможності економіки країни / 3.В. Юринець, О.В. Макара // Ефективна економіка. - 2016. - № 2. [Електронний ресурс]. - Режим доступу: http://www.economy.nayka.com.ua/?op=1\&z=4772.

10. Євтушенко В. А. Інноваційна діяльність як сфера соціальної відповідальності українських підприємств / В. А. Євтушенко, Б. В. Сорін, А. І. Бабошко // Наук. вісник ХДУ. Серія «Економічні науки». - Херсон. - 2016. - Вип.16. - Ч. 1. - С. 9-15.

11. Сорін Б. В. Індикатори інноваційності національної економіки / Б. В. Сорін // Перспективи розвитку національної економіки: зб. матеріалів МНПК (м. Запоріжжя, 12-13 лютого 2016 року) - У 2-х ч. - Запоріжжя: ГО «СІЕУ», 2016. - Ч. 2. - 144 с.- С. 119 - 122.

12. The Global Innovation Index 2017. Innovation Feeding the World [Electronic resource] Accessed mode: https://www.globalinnovationindex.org/gii-2017-report

13. Worldwide Central Bank Rates [Electronic resource] - Accessed mode: http://www.cbrates.com/ 
14. WIPO International statistics property data center [Electronic resource] - Accessed mode: http://ipstats. wipo.int/ipstatv2/index.htm?tab=patent.

15. The Global Innovation Index 2013 The Local Dynamics of Innovation [Electronic resource] Accessed mode: https://www.globalinnovationindex. org/userfiles/file/reportpdf.

16. IMF Data International Financial Statistics [Electronic resource] - Accessed mode: http://data.imf.org/?sk=5DABAFF2-C5AD-4D27-A175-1253419C02D1.

17. The Global Innovation Index 2016 Winning with Global Innovation [Electronic resource] Accessed mode: http://www.wipo.int/edocs/pubdocs/en /wipo_pub_gii_2016.pdf.

\section{References}

1. Geets V.M. (2015) Innovative Ukraine 2020. National Report. National Academy of Sciences of Ukraine. Kyiv:Natsionalna academia nauk Ukrainy (in Ukr.) .

2. Nelson, R.,(1993). National Innovation Systems: A Comparative Analysis. New York Oxford: Oxford University Press.

3. Lundvall, B. (2007). National innovation systems-analytical concept and development tool. Industry and Innovation, 14.1,95-119.

4. Soete, L., Verspagen B., \& Weel B. ter (2010). Systems of innovation. UNU-MERIT Working Papers. Maastricht Economic and Social Research and Training Center for Innovation and Technology. Maastricht: UNU-MERIT.

5. Tereshkina, N. (2015). Innovation policy as an instrument for implementation of the National Innovation Strategy. Ekonomika rozvytku. (Economy of Development), 2, 21-29 (in Ukr.).

6. Lebedeva, L. (2014). Modern innovation policy of the state in Ukraine: problems and perspectives of reforms Efektivna Ekonomika (Effective Economics), 1. Retrieved from http://www.economy.nayka.com.ua/?op=1\&z=2664 (in Ukr.).

7. Golovinov, O. (2013). Innovation policy of the state: realities and problems. Ekonomichniy buleten Universitetu:kollektsiya naukovih prats Pereyaslav-Khmelnitskogo Derzhavnogo Universitetu (Economic Bulletin of the University: a collection of scientific works of Pereyaslav-Khmelnytsky State Pedagogical University),21 (1), 16-21 (in Ukr.).

8. Anisimov, I. (2015). State policy of Ukraine concerning the development of innovation activity in the conditions of the economic crisis.Bulleten Priazovskogo Derzhavnogo Tehnichnogo Universitetu.Seriya:Ekonomichni nauky (Bulletin of the Priazovsky State Technical University. Series: Economic Sciences), 30, 255-261 (in Ukr.).

9. Yurinets, Z., Makara, O. (2016). Innovation policy as a tool for improving the competitiveness of the country's economy. Efektivna Ekonomika (Effective economy), 2. Retrieved from http://www.economy.nayka.com.ua/?op=1\&z=4772 (in Ukr.).

10. Yevtushenko, V., Sorin, B., Baboshko, A. (2016). Innovative activity as a sphere of social responsibility of Ukrainian enterprises. Naukoviy Bulleten KHDU. Seriyi "Economichni Nauky"( Science Bulletin of the KHDU. Series "Economic Sciences") , 16-1, 9-15.

11. Sorin, B. (2016). Indicators of innovation of the national economy. Prospects for the development of the national economy. Sbirnyk materialov MNPK (m.Zaporizhya,12-13.02.2016). (A Collection of materials of MNPK (Zaporizhya, 12-13.02.2016) .In 2 parts.Zaporizhya: SUEU, Ch. $2,119-122$.

12. The Global Innovation Index (2017). Innovation Feeding the World Retrieved from https://www.globalinnovationindex.org/gii-2017-report.

13. Worldwide Central Bank Rates.(2018) Retrieved from http://www.cbrates.com.

14. WIPO International Statistics Property Data Center.(2018). Retrieved from http://ipstats. wipo.int/ipstatv2/index.htm?tab=patent.

15. The Global Innovation Index (2013). The Local Dynamics of Innovation Retrieved from https: //www.globalinnovationindex. org / userfiles / file / reportpdf.

16. IMF Data International Financial Statistics.(2018). Retrieved from http://data.imf.org/?sk=5DABAFF2-C5AD-4D27-A175-1253419C02D1.

17. The Global Innovation Index. (2016). Winning with Global Innovation. Retrieved from http://www.wipo.int/edocs/pubdocs/en/wipo pub gii 2016.pdf. 